\title{
Determining the Moderating Role of Supervisory Support on the Relationship Between Organization Career Management and Employee Career Satisfaction: Evidence from Private Insurance Companies in Ghana.
}

\author{
${ }^{1}$ Benard Korankye*, ${ }^{2}$ Seidu Musah, ${ }^{3}$ Okafor Adakwelu Ifeamalume \\ ${ }^{1,2,3}$ School of Management, Jiangsu University, No.301, Xuefu Road, Zhenjiang city, Jiangsu province,
} China

\begin{abstract}
The purpose of this study was to determine the moderating role of supervisory support on the relationship between organizational career management and career satisfaction of employees of selected five private insurance companies in Ghana. A survey method was used to collate information from 167 employees who work in the studied organizations through a simple random sampling approach. The descriptive, correlation, multiple regression, and the moderated multiple regression analysis were used to test the research hypothesis and their results showed three important findings: firstly, organizational career management positively and significantly correlates and had an impact on career satisfaction. Secondly, supervisory support positively and significantly correlates and had an impact on career satisfaction. Lastly, the moderating role of supervisory support was established to be positive and significant on the relationship between organizational career management and career satisfaction. The outcome contributes to the Job Demand Resource (JD-R) theory such that organizational career management and supervisory support could be employed as organizational resources to produce career satisfaction. The study suggests that more attention and commitment should be given to organizational career management and supervisory support by the management of the private insurance companies to promote the career satisfaction of their employees.
\end{abstract}

Keywords: organizational career management, supervisory support, career satisfaction.

\section{Introduction}

In the $21^{\text {st }}$ century, one critical issue which is mostly discussed among major stakeholders of an organization is career management. Due to this, many organizations have come up with appropriate models that seek to develop the career of the human resources at their disposal and are mostly championed by human resource managers or experts (Paul \& Jansen, 2014). The scope of organizational career management consists of elements such as planning and managing all aspects of human resources, which includes the monitoring of employee attitude, affairs, wellbeing, and areas of interest of employees while at work for an organization (Ismail et al., 2011; Neary et al., 2015). In many organizations, the decision and authority to develop and manage the career progress of employees are left in the hands of supervisors or immediate managers. To realize this objective, human resource managers join hands with supervisors in planning and designing career programs and activities that help in establishing a balance between individual career needs, organizational requirements, future organizational innovations, and what an employee stands to gain relative to other future endeavors (Rothwell et al., 2015). These programs help companies retain and empower topskilled employees; increase engagement and productivity; reinforce the succession plan for talented individuals; increase the transmission and retention of knowledge; fill internal skills and function disparities, and create a positive image for the organization (Ismail et al., 2011, 2017).

However, despite the growing concern of the contributions of organizations towards the career of their employees, one question that remains unanswered is the critical role supervisors play relative to the career advancement or satisfaction of their subordinates (Fleisher et al., 2014). Furthermore, calls for more 
research into the role of supervisors in organizational career management to promote career satisfaction are rare and have not attained the needed attention (Kraimer et al., 2011). Sometimes, findings from some studies look controversial as they seek to downplay the relevance of supervisors in the career management of their subordinates. Other researchers are of the view that a poor relationship between supervisors and their subordinates would amount to a negative contribution towards their career and urged organizations to focus on acquiring experts who can shape the career pattern of their employees other than relying on the contributions from supervisors (Jin \& McDonald, 2017).

Additionally, this study builds its foundation relying on the Job Demand Resource (JD-R) Theory but dwells solely on the aspect of the theory which speaks to resources that should be made available to an individual to enable him or her perform better in a job i.e. the job resources aspect of the theory. It is believed that once resources in an organization are prudently managed and made available to players of the organization, several behavioral and organization outcomes are produced (Cho et al., 2020). A resource in an organization does not only refer to the tangibles but also the intangibles that are made available to an employee to perform well (Bakker \& Demerouti, 2017). It must be stated that the human resources comprising of management, shareholders, supervisor, managers, employees among others makeup an important resource of an organization and once employed well would be a game-changer (van Woerkom et al., 2016). Moreso, programs initiated by these organizational players affects the entire business operation. According to Cho et al., (2020) organizational and supervisory support, appropriate working environment, and opportunity for advancement could serve as a resource used by an organization to produce a behavior. This study hence posits that organizational career management and supervisory support could be used as an important resource to promote career satisfaction among employees.

This paper further aims to contribute to the discussion by offering evidence of the positive impact of career management on employee's career satisfaction. An important point of departure is that this study focuses on organizational career management i.e. the support that is rendered by the organization towards the career of its employees and not what individual workers do for themselves relative to their careers i.e. individual career management (Karavardar, 2014). Organizational career management refers to the approach, programs, and mechanisms that organizations constitute to develop the careers of their employees (Weng \& McElroy, 2012).

Furthermore, the study would address the role of supervisory support on the relationship between organizational career management and career satisfaction. It would ascertain if supervisory support could affect how organizations contribute to the career of their employees. Supervisory support is said to be the extent to which supervisors appreciate subordinates' efforts and care for their well-being. This is manifested by showing concern and care towards the career goals of employees, appreciating employees for completed work, recommending them for promotions, providing timely and appropriate information to subordinates, help them obtain skills and competencies relevant to their field and create a sense of belongingness among his subordinates (Rucha, 2013).

Therefore, the study seeks to examine two questions in the paper: what is the impact of OCM on career satisfaction? And, what is the role of supervisory support in this relationship? The study would test this moderated relationship in a quantitative investigation with employees from the private insurance companies in Ghana.

The paper makes various contributions to the literature on OCM, supervisory support, and career satisfaction. First, the study provides empirical evidence supporting the growing but yet limited research on the potential positive impact of OCM and supervisory support on career satisfaction (e.g. Osibanjo et al., 2014). Additionally, the study would explain the mechanisms that facilitate the work by testing the role of supervisory support on the relationship between OCM and career satisfaction. By doing so, the study responds to calls on literature for research examining supervisory support as not only an independent variable or a predictor but also an instigating mechanism (Wickramasinghe \& Jayaweera, 2010). Conclusively, the research contributes to the literature on OCM, supervisory support, and career satisfaction by highlighting the interdependency between individuals, supervisors, and the organization and stating clearly the impact of supervisors and the organization on their employees relative to their career satisfaction. 


\section{Literature review}

The Job-Demand Resource (JD-R) theory posits to speak to the well-being of employees in a situation where the demands of their job exceed the resources made available to them and also where demands of their job correspond to the resources made available (Bakker \& Demerouti, 2014, 2017). Once the demands are high but resources are low, employees become stressed. However, when demands are high and resources are high, performance is increased, engagement is established and satisfaction is derived (Cho et al., 2020). The job resource of the theory defines the social, psychological, and physical organizational elements that are made available for an employee to achieve his or her set target (Bakker \& Demerouti, 2014). These resources include an appropriate working environment, an opportunity for promotion, training, and development, coaching, and mentoring as well as autonomy (van Woerkom et al., 2016).

A recent review of literature relative to the development of human resources in various organizations reveals that studies on career management come in two forms which are organizational career management and individual career management (Kong et al., 2015). From the perspective of the organization, career management refers to the programs, activities, and measures put in place by organizations to improve, advance, and sustain the career development of employees enabling them to obtain a promotion, pay rise, knowledge expansion, essential skills, and assist to transit into leadership (Mineva et al., 2020). Conceptually, organizations that provide a platform for career advancement position employees to be motivated, more useful, and resourceful. Employees invariably also use what they acquire during career programs and activities to enhance their contributions and more responsible for the task they have been assigned. Employees have a major insight into their responsibilities, obtain a higher degree of independence and the fear of being redundant in the foreseeable future is eradicated (Rothwell et al., 2015). Organizational career management in effect affects employees' performance, commitment, and satisfaction. Meanwhiles, organizations must endeavor to pursue a holistic plan to transform essentially the career pattern of their employees specifically to suit the current organizational, industrial, and individual employee's needs. OCM also enhances the capacities of the employee to perform to the best of their abilities and also become satisfied with the contribution of their organization (Thunnissen, 2016).

Additionally, walk-through literature on the investigation of OCM over the years shows that there is a relationship between career management and subjective career outcomes in this case career satisfaction (Chiaburu et al., 2013). Writing from the domain of career behavior, career satisfaction is defined broadly from a multi-dimensional psychological response to a person's job; and these personal responses have a cognitive (evaluative), affective (emotional), and behavioral aspect (Ismail et al., 2016). Personal and/or social factors greatly affect the degree to which an individual feels connected to or alienated from a job or profession. If a person feels strongly linked to a job or occupation, these feelings may result in a person experiencing substantial career satisfaction with jobs in an organization (Spurk et al., 2019). Career satisfaction serves as a means of measuring people's perceptions relative to their career advancement. It is often termed as the success an individual attains from the angle of his or her career and therefore classified as a big indicator of subjective career success (Lee, 2016). The idiosyncratic evaluation by employees of their career is known as career satisfaction. It speaks to the progression one has made towards achieving their career objectives (Spurk et al., 2015).

Several extant studies that examine the success organizations obtain highlights the ability of management to appropriately make use of their supervisory support in various blocs of the organization to have a significant impact on employee outcomes, especially in the area of career satisfaction (Carasco-Saul et al., 2015; de Oliveira et al., 2017; Wickramasinghe, 2010). From the perspective of organizational behavior, supervisory support can be characterized as the degree to which supervisors acknowledge the contributions of subordinates and tend to their well-being (Suan \& Nasurdin, 2016). This is shown by showing consideration and caring for employees ' career goals, appreciating employees for work done, approving them for promotions, providing subordinates with timely and adequate information, helping them learn skills and competencies related to their profession, and fostering a sense of belonging among their subordinates (Jin \& McDonald, 2017). It is said that a creative supervisor is the builder of supervisor-employee relationships and encourages teamwork between all workers under his care (Chan, 2017; Fukui et al., 2019; Pandey et al., 2018). 
2.1 The relationship between Organizational Career Management and Career Satisfaction.

According to Wesarat et al., (2014), organizational career management is emphasized as crucial to career satisfaction and success, since the chapter of OCM provides the platform for career advancement of employees either to progress with the same organization or move across several others. Guan et al., (2015); Kong et al., (2012) at the end of their studies concluded that career satisfaction could be promoted through organizational career management and not downplaying the fact that organizations must consider carefully what employees need relative to their career advancement to develop appropriate career models. Hagiwara et al., (2014) were of the view that "organizational career management could be used as a stone in killing two birds" i.e. promoting career satisfaction and advancing employee retention. The study argues that the availability of career progression programs in an organization alone contributes to some level of satisfaction to the employees. Lewis \& Arnold, (2012) posits that OCM activities such as educational and training opportunities, performance appraisal for career planning, and mentorship have been adopted by various organizations to manage the careers of their employees which invariably results in career satisfaction and commitment. The study established that OCM is positively related to career satisfaction. Chiaburu et al., (2013); De Vos \& Segers, (2013) indicated that employees' career satisfaction could be realized when the organization has programs and measures that suit their career needs and desires. Failure on the part of the organization could result in a boycott of work, labor turnover, and other industrial actions. McGuire et al., (2010) indicate that employees are more satisfied with their careers when there are opportunities for advancement and an equal playing field for all after completing a career designed program put in place by the organization. Based on the above evidence, this study proposes that;

\section{H1 - There will be a significant and positive impact of OCM on career satisfaction.}

\subsection{The relationship between Supervisory Support, Organizational Career Management, and Career} Satisfaction.

One important aspect that affects the career advancement and opportunities of employees is supervisory support. A well-defined positive relationship between employees and supervisors plays an important role in enhancing career growth for employees. Supervisory support was established as a critical element in promoting career satisfaction (Kang et al., 2015). In the form of therapy, acknowledgment, friendships, sponsorships, praise, and psychosocial roles are ways in which supervisors support workers. An effective relationship between superiors and their subordinates results in boosting the careers of employees thereby resulting in satisfaction (Saleem \& Amin, 2013). Even though different literature suggests that it is the sole duty of employees to improve their careers and make themselves better off, it is also a fact that it would require the necessary and unflinching help of superiors. Furthermore, regardless of how loyal or committed employees would be, they may not be able to manage their careers efficiently and would thus need the assistance of supervisors (Arthur et al., 2005). There is some evidence that the degree of supervisoremployee interactions has a positive effect on employee personal career development and thus translates into career satisfaction (Kalliath et al., 2012). Based on the above literature, there has been evidence that supervisory support and career satisfaction are strongly associated. It may be argued that supervisory support may have a positive impact on career satisfaction. This study, therefore, proposes that:

\section{H2 -There will be a significant and positive impact of supervisory support on career satisfaction.}

\section{H3 - Supervisory support positively moderates the relationship between OCM and career satisfaction.}




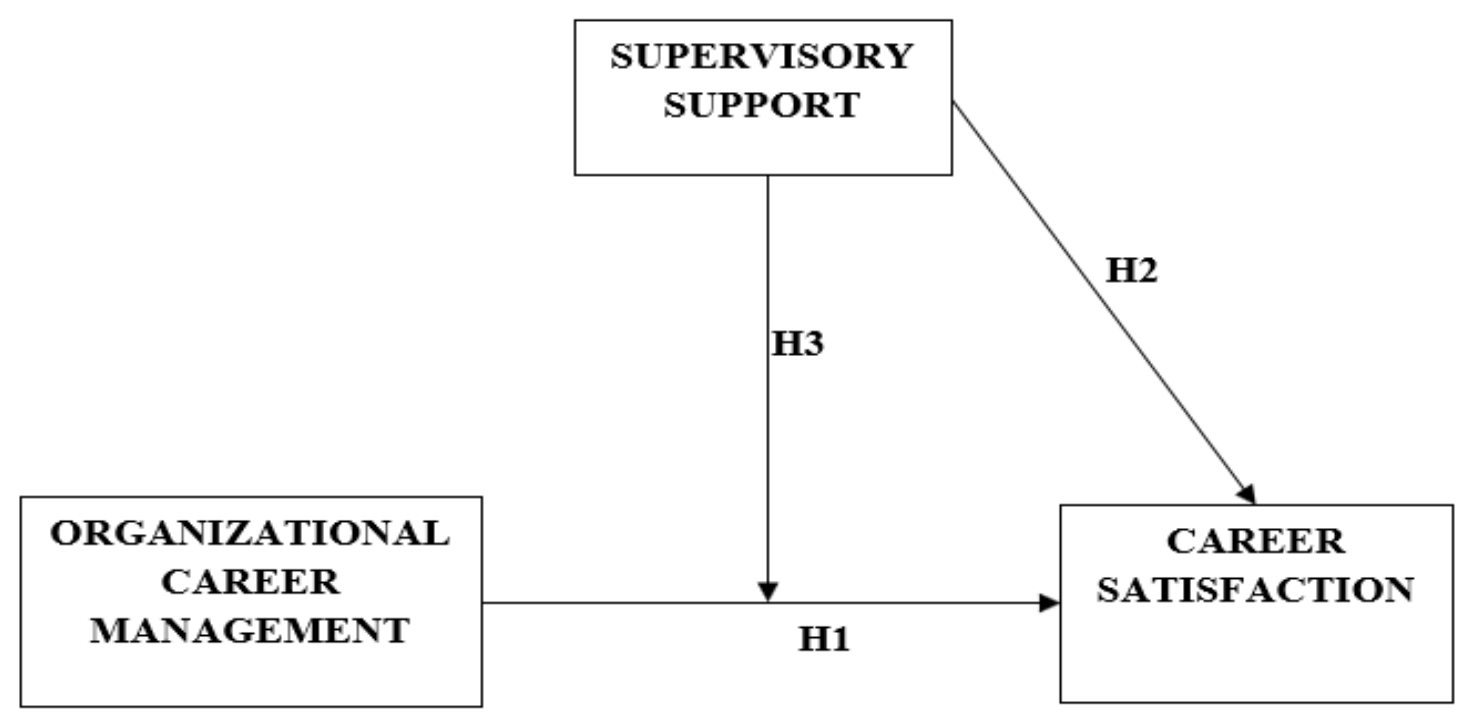

Figure 1 Conceptual framework of the study.

\section{Methodology}

This section discusses the research design, study population, data sources, data collection, and as well as data analysis strategies.

\subsection{Research design}

The research design refers to the roadmap or set of guidelines employed by a researcher to examine, conceptualize, and give answers to the questions posed by a study. It factors items such as data collection, data analysis approach, and the population of the study. This study opted to use a quantitative and crosssectional research approach. The quantitative approach is mostly used when constructs in a study can be measured in terms of quantity and used the outcome to test the objective of theories. A cross-sectional approach is often used to take a snapshot description of the sampled population at a particular point in time.

\subsection{Research population, sampling, and sample size}

The study population is all full-time employees in five selected insurance companies in the Kumasi Metropolitan Assembly of Ghana (Donewell Insurance Co. Ltd, Starlife Assurance Co. Ltd, Metropolitan Life Insurance Gh. Ltd, Vanguard Assurance Co. Ltd, and Absa Group Ltd). To select from the population, the simple random sampling technique was used which sort to provide every item of the population the same and known chances of being nominated. The simple random sampling technique is said to be less expensive relative to the time when you want to undertake a survey. It is, however, important to state that employees of the insurance companies have fair knowledge and preview of the elements of the study. The study uses samples of 167 for the analysis and discussions.

\begin{tabular}{|l|l|l|l|}
\hline Unit of analysis & $\begin{array}{l}\text { Population of } \\
\text { study }\end{array}$ & Sample Size & $\begin{array}{l}\text { Sampling } \\
\text { Approach }\end{array}$ \\
\hline Donewell Insurance Company Limited. & Employees & 32 & Random \\
\hline Starlife Assurance Company Limited & “ & 35 & “ \\
\hline Metropolitan Life Insurance Ghana Limited & “ & 23 & “ \\
\hline Vanguard Assurance Company Limited & “ & 31 & “ \\
\hline Absa Group Limited & “ & 46 & “ \\
\hline
\end{tabular}

The total sample size is 167 participants. 


\subsection{Sources of data and research instrument.}

Data used for this research emanates from two sources which are primary and secondary. The primary data is referred to as the first-hand information gathered by a researcher relative to a problem under study. The secondary data refers to information that is already in existence. The study fell on articles from reputable journals, books, and information from some online portals to establish the relationship among elements.

The research instrument is questionnaires. Questionnaires are a way of collecting data in form of questions sent or given directly to be filled and returned. An online questionnaire was used to gather data from the population of the study (employees of five selected insurance companies). A total of 179 questionnaires were sent via various apps to the participants. 167 participants fully completed the survey which was adopted and used for the study with 12 participants unable to complete the survey and therefore it was rejected. This shows a response rate of $93.3 \%$. The questionnaire had three sections with the first and second sections covering the demographic nature of respondents and general information on OCM and supervisory support. The Liker scale of the fifth continuum from 1 to 5 ( $1=$ strongly disagree, $2=$ disagreed, $3=$ neutral, $4=$ agree, and 5= strongly agree) was used in measuring relationships among variables in the third section of the questionnaire.

\subsection{Operationalizing variables.}

The independent variable (organizational career management -OCM) was measured using five items adapted from (Lee \& Brown, 2003: Chen et al., 2004). The dependent variable (career satisfaction) was measured using five items adapted from (Greenhaus et al., 1990). The moderator (supervisory support) was measured using five items expunge from (Greenhaus et al., 1990).

\subsection{Data analysis and presentation.}

Information that was obtained from participants were coded and processed through the Statistical Package for Social Sciences (SPSS version 26). The descriptive analysis in percentages and the measure of central tendencies (mean) would be undertaken to determine the influence of independent variables on the dependent variable. The descriptive analysis helps the researcher to meaningfully define the distribution of measurements and analyze the output. Additionally, the multiple regression analysis would be conducted to determine how changes in the independent variables would result in a positive, negative, significant, or insignificant impact on the dependent variable. The regression model in this study was:

$$
Y=\beta_{0}+\beta_{1} X_{1}+\beta_{2} X_{2}+\varepsilon .
$$

Equation (1)

Where $\mathrm{Y}=$ Career Satisfaction (dependent variable), $\mathrm{X}_{1}=$ Organizational Career Management (independent variable), $X_{2}=$ Supervisory Support (moderating variable), $\varepsilon=$ Error term; $\beta_{0}, \beta_{1}, \beta_{2}$, = unknown parameters.

\section{Results and Discussion \\ 4.1 Demographic information of respondents}

Table 1 Socio-demographic profile of respondents.

\begin{tabular}{|l|c|c|}
\hline Participants characteristics & Sub-profile & Percentage (\%) \\
Gender & Male & 55.1 \\
Age & Female & 44.9 \\
& 18-25 years & 38.9 \\
& 26-35years & 44.3 \\
Education Qualification & 36-45 years & 10.8 \\
& 46 years and above & 6.0 \\
& WASSCE & 3.6 \\
& Diploma & 15.0 \\
& HND & 24.6 \\
Length of service & Degree & 52.1 \\
& Others & 4.8 \\
& Below 1 year & 29.9 \\
& 1-5 years & 49.1 \\
\hline
\end{tabular}




\begin{tabular}{|l|c|c|}
\hline & 6-10years & 13.8 \\
Income level & 11 years and above & 7.2 \\
& GHC $800-1000$ & 42.5 \\
& GHC $1100-1500$ & 38.9 \\
& GHC 1600 and above & 18.6 \\
\hline
\end{tabular}

Table 1 indicates the demographic features of all the 167 participants which cover $55.1 \%$ male and $44.9 \%$ female. $38.9 \%$ of the participants are between ages $18-25$ years, $44.3 \%$ are between $26-35$ years, $10.8 \%$ are between 36-45 years, and 6.0\% are 46 years and above. 3.6\% of the participants (employees) have obtained WASSCE, followed by $15.0 \%$ of Diploma, followed by $24.6 \%$ of HND, followed by $52.1 \%$ of Degree and $4.8 \%$ who had other forms of educational qualifications. $29.9 \%$ of the participants had been in their organization below 1 year, $49.1 \%$ of them had spent 1 -5years in their organization, $13.8 \%$ had been in their organization for 6-10years and 7.2\% of participants had been in their organization for 11 years and above. The majority of the participants had an income level of GHC $800-1000$ i.e., $42.5 \%$, followed by $38.9 \%$ with an income level of GHC $1100-1500$ and $18.6 \%$ with an income of GHC 1600 and above.

\subsection{Descriptive statistics}

Table 2 Descriptive Statistics

\begin{tabular}{|l|r|r|r|}
\hline & Mean & Std. Deviation & N \\
\hline Career Satisfaction & 3.9482 & .55658 & 167 \\
\hline OCM & 4.1928 & .66602 & 167 \\
\hline Supervisory Support & 4.2747 & .44227 & 167 \\
\hline
\end{tabular}

The outcome in table 4.2 provides descriptive statistics for all constructs. The results indicate that supervisory support has the highest mean of 4.2747 and the lowest standard deviation of 0.44227 . The mean of OCM is 4.1928 and the highest standard deviation of 0.66602 . The mean of career satisfaction is 3.9482 and the standard deviation of 0.55658 .

\subsection{Validity and Reliability}

A various statistical test is undertaken to determine the reliability of a measuring model. This is to ascertain the authenticity of the data gathered. According to Kothari, (2008), the Barlett test, the KMO test, Cronbach Alpha among others are used to determine the reliability of the data. This study adopted the Cronbach Alpha coefficient to determine the reliability of the model. The golden rule is that if Cronbach Alpha is more than 0.7, the model is said to be good, acceptable, and reliable. Table 3 reports the Cronbach Alpha values of the model of the study, OCM $=0.723$, supervisory support $=0.736$, and career satisfaction $=0.702$. The study then concludes that the measurement model is reliable and also display higher inner consistency.

Table 3 The Cronbach Alpha table.

\begin{tabular}{|c|c|c|}
\hline Variables & Cronbach Alpha & No. of items \\
\hline OCM & 0.723 & 10 \\
\hline Supervisory support & 0.736 & 10 \\
\hline Career Satisfaction & 0.702 & 5 \\
\hline
\end{tabular}




\subsection{Correlation Analysis.}

The Pearson correlation analysis was employed to determine the strength of the relationship between the constructs of the study. The significant level for the correlation coefficient was set at the 0.05 level (1tailed). According to Hair et al., (2010), the strength of the relationship can be ascertained with the Pearson Correlation ( $r$ ). According to the study, when $r=0$ means there is no correlation, $r=1$ means there is a perfect correlation, and when $r=-1$ means there is a negative correlation. The rules determining the strength of the relationship matrix is: ( $\mathrm{r}=0.10$ to 0.29 or $\mathrm{r}=-0.10$ to -0.29 means small correlation), $(\mathrm{r}=0.30$ to 0.49 or $\mathrm{r}=-0.30$ to -0.49 means medium correlation) and ( $\mathrm{r}=0.5$ to 1 or $\mathrm{r}=-0.5$ to -1 means strong correlation) (Hair et al., 2009).

Table 4 indicates that there is a significant relationship between variables. There is a medium but positive correlation between OCM and career satisfaction with $r=0.367$. This statistical evidence shows that there is a relationship between OCM and career satisfaction among the employees of these private insurance companies in Ghana. The outcome is consistent with results in (Kong et al., 2015; Wang \& Wanberg, 2017) which also established a positive correlation between organizational career management and career satisfaction. Additionally, there is a small but positive correlation between supervisory support and career satisfaction with $r=0.117$. This result reveals that the support offered by various supervisors in the selected private insurance companies has a connection to the career satisfaction of their employees. The outcome of the study is in tandem with results from Kang et al., (2015); Karatepe \& Olugbade, (2017) which posits that the roles of supervisors are critical to the advancement of employee's career and promotes career satisfaction.

\begin{tabular}{|l|l|r|r|r|}
\hline \multicolumn{7}{|c|}{ Table 4 correlational matrix } \\
\hline \multicolumn{2}{|c|}{} & $\begin{array}{c}\text { Career } \\
\text { Satisfaction }\end{array}$ & $\begin{array}{c}\text { Supervisory } \\
\text { Support }\end{array}$ \\
\hline Pearson Correlation & CS & 1.000 & & \\
\cline { 2 - 5 } & OCM & .367 & 1.000 & \\
\cline { 2 - 5 } & SS & .117 & .279 & 1.000 \\
\hline
\end{tabular}

\subsection{Multiple regression analysis}

The multiple regression analysis was undertaken to determine the impact of the independent variables on the dependent variable of the study. The regression defines the extent to which the model explains the dependent variable through the model summary. Table 5 presents the model summary of the study where $\mathrm{R}$ is reported to be 0.767 and $\mathrm{R}^{2}$ of 0.735 . This presupposes that the independent variables explained about $73.5 \%$ of the variations in the dependent variable. This also means that $26.5 \%$ of the variables are defined by other factors not accounted for by this study.

\begin{tabular}{|c|c|c|c|c|c|}
\hline \multicolumn{6}{|c|}{ Table 5 The Model Summary } \\
\hline \multirow[t]{2}{*}{ Model } & \multirow[t]{2}{*}{$\mathrm{R}$} & \multirow[t]{2}{*}{ R Square } & \multirow[t]{2}{*}{$\begin{array}{l}\text { Adjusted R } \\
\text { Square }\end{array}$} & \multirow[t]{2}{*}{$\begin{array}{l}\text { Std. Error of } \\
\text { the Estimate }\end{array}$} & $\begin{array}{l}\text { Change } \\
\text { Statistics }\end{array}$ \\
\hline & & & & & Sig. F Change \\
\hline 1 & $.767^{\mathrm{a}}$ & .735 & .724 & .52095 & .000 \\
\hline \multicolumn{6}{|c|}{ a. Predictors: (Constant), Supervisory Support, OCM } \\
\hline \multicolumn{6}{|c|}{ b. Dependent Variable: Career Satisfaction } \\
\hline
\end{tabular}

The study used the statistical $\mathrm{F}$ test and its significance to ascertain how well the regression equation fits the data. Concerning this study, the F-value $=12.673$ and significant at 0.000 showing that the independent variables i.e., OCM and supervisory support helped to explain some variations in the dependent variable i.e., 
career satisfaction. The ANOVA outcome is a testimony that the entire model was significant and therefore the predictors were good joint explanatory determinants of career satisfaction.

\begin{tabular}{|l|l|r|r|r|r|r|}
\hline \multicolumn{2}{|c|}{ Table 6 ANOVA } \\
\hline \multicolumn{2}{|c|}{ Model } & $\begin{array}{c}\text { Sum of } \\
\text { Squares }\end{array}$ & \multicolumn{1}{c|}{ df } & Mean Square & F & Sig. \\
\hline \multirow{3}{*}{1} & Regression & 6.879 & 2 & 3.439 & 12.673 & $.000^{\mathrm{b}}$ \\
\cline { 2 - 7 } & Residual & 44.236 & 163 & .271 & & \\
\cline { 2 - 7 } & Total & 51.114 & 165 & & & \\
\hline \multicolumn{2}{|l|}{ a. Dependent Variable: Career Satisfaction } \\
\hline \multicolumn{2}{|l}{ b. Predictors: (Constant), Supervisory Support, OCM } \\
\hline
\end{tabular}

At a $5 \%$ level of significance and a $95 \%$ level of confidence, the study ascertained the impact of the independent variable through the coefficient of determination. The regression equation employed established that by making all determinants to be zero (OCM and supervisory support), career satisfaction will be $2.593(25.93 \%)$.

Additionally, the regression coefficient of $\mathrm{OCM}\left(\mathrm{X}_{1}\right)$ is 0.303 which is significant at $\mathrm{p}<0.05$. This means that the variable OCM $\left(\mathrm{X}_{1}\right)$ affects the dependent variable career satisfaction $(\mathrm{Y})$ of $0.303(30.3 \%)$. By implication, a $1 \%$ change in OCM results in a $30.3 \%$ change in career satisfaction. Organizational career management has a positive and significant impact on career satisfaction among employees in the private insurance companies in Ghana. The outcome of the study is in tandem with outcomes Karavardar, (2014); Rothwell et al., (2015); Saleem \& Amin, (2013); Wesarat et al., (2014) which present that organizations should pursue rigorously in putting up career programs and activities that are in line with their objectives and employee needs to enhance career satisfaction. Kong et al., (2015) believe that achieving career satisfaction is properly managed in the organizational context and admonished all organizations to champion the career progression of their employees.

Furthermore, supervisory support $\left(\mathrm{X}_{2}\right)$ regression coefficient value of 0.222 means that the variable supervisory support $\left(\mathrm{X}_{2}\right)$ affects the variable career satisfaction $(\mathrm{Y})$ of $0.222(22.2 \%)$. This means that a unit increase of supervisory support would result in a $22.2 \%$ increase in career satisfaction. The outcome is an indication that supervisors contribute to the career satisfaction of employees in the private insurance companies in Ghana. The outcome is consistent with results from Lambert et al., (2016); Pandey et al., (2018) which indicates that supervisors should be well-resourced, motivated, and empowered to support their subordinates relative to their career. It is believed that the supervisor's role should be incorporated in designing career models for employees for them to be effective in managing the careers of employees (Kraimer et al., 2011). Conclusively, the regression equation with the Beta values is $\mathbf{Y}=\mathbf{2 . 5 9 3}+\mathbf{0 . 3 0 3 X}_{\mathbf{1}}+$ $\mathbf{0 . 0 2 0 X}_{2}+\varepsilon$.

\begin{tabular}{|c|c|c|c|c|c|c|}
\hline \multicolumn{7}{|c|}{ Table 4 Coefficient of determination between predictors and the dependent variable. } \\
\hline \multirow{2}{*}{\multicolumn{2}{|c|}{ Model }} & \multicolumn{2}{|c|}{$\begin{array}{l}\text { Unstandardized } \\
\text { Coefficients }\end{array}$} & \multirow{2}{*}{$\begin{array}{c}\begin{array}{c}\text { Standardized } \\
\text { Coefficients }\end{array} \\
\text { Beta }\end{array}$} & \multirow[t]{2}{*}{$\mathrm{t}$} & \multirow[t]{2}{*}{ Sig. } \\
\hline & & B & Std. Error & & & \\
\hline \multirow[t]{3}{*}{1} & (Constant) & 2.593 & .422 & & 6.139 & .000 \\
\hline & OCM & .303 & .063 & .362 & 4.770 & .000 \\
\hline & $\begin{array}{l}\text { Supervisory } \\
\text { Support }\end{array}$ & .222 & .095 & .016 & .213 & .004 \\
\hline
\end{tabular}




\subsection{Moderation analysis}

The regression analysis which determines the impact of a predictor on an outcome through the introduction of a third variable called the moderator is known as the moderation analysis (Hair et al., 2010). Supervisory support is the moderator of the study and sort to moderate the relationship between OCM and career satisfaction. The moderating role of supervisory support was undertaken using moderated multiple regression (MMR) analysis where the change in $\mathrm{R}$ squared is used to discuss the moderation role of the moderator.

To ascertain the moderating effect, the equation for the MMR model was indicated as:

$$
\begin{aligned}
& Y=i 1+b 1 X_{1}+c 1 Z_{1}+e 1 \\
& Y=i 2+b 2 X_{2}+c 2 Z_{2}+d 2\left(X^{*} Z\right)+e 2
\end{aligned}
$$

Where: $\mathrm{Y}=$ dependent variable;

$\mathrm{X}=$ independent variable;

$\mathrm{Z}=$ moderator

$\mathrm{X}^{*} \mathrm{Z}=$ the multiplier of independent variable and moderator (the interaction effect).

$\mathrm{i}=$ constant value for independent variable

$\mathrm{b}, \mathrm{c}, \mathrm{d}=$ coefficients for independent variable and moderator and $\mathrm{e}=$ regression residual.

Table 5 Moderation models using $R$-squared Significance change of variables

\begin{tabular}{|l|l|l|l|l|l|l|l|l|l|}
\hline $\begin{array}{l}\text { Independent } \\
\text { variable (s) }\end{array}$ & $\mathrm{R}$ & $\begin{array}{l}\mathrm{R} \\
\text { square }\end{array}$ & $\begin{array}{l}\text { Adjusted } \\
\mathrm{R} \text { square }\end{array}$ & $\begin{array}{l}\text { Std. } \\
\text { error of } \\
\text { the } \\
\text { estimate }\end{array}$ & $\begin{array}{l}\mathrm{R} \\
\text { square } \\
\text { change }\end{array}$ & $\begin{array}{l}\mathrm{F} \\
\text { change }\end{array}$ & df1 & df2 & $\begin{array}{l}\text { Sig. F } \\
\text { change }\end{array}$ \\
\hline $\mathrm{X}_{\mathrm{i}}$ & $.707^{\mathrm{a}}$ & .734 & .729 & 0.51943 & .734 & 25.449 & 1 & 164 & 0.000 \\
\hline $\mathrm{X}_{1}$ and $\mathrm{Z}_{2}$ & $.767^{\mathrm{b}}$ & .735 & .724 & 0.52095 & 0.001 & 12.673 & 2 & 163 & 0.001 \\
\hline $\mathrm{X}_{1} \mathrm{Z}_{2}$ and & $.769^{\mathrm{c}}$ & .746 & .720 & 0.52211 & 0.011 & 8.503 & 3 & 162 & 0.000 \\
\hline $\mathrm{X}_{1} * \mathrm{Z}_{2}$ & & & & & & & & & \\
\hline
\end{tabular}

Dependent Variable: Y (Career Satisfaction)

The conditional effect of OCM $\left(\mathrm{X}_{\mathrm{i}}\right)$ was established to be significant on career satisfaction (Y). The outcomes show that the model explains $73.4 \%$ of the changes in the dependent variable. Adding supervisory support $\left(\mathrm{Z}_{\mathrm{i}}\right)$ to the equation containing $\mathrm{OCM}\left(\mathrm{X}_{\mathrm{i}}\right)$ as a predictor improved the $\mathrm{R}^{2}$ by 0.001 which was significant at $\mathrm{p}=0.001$. The $\mathrm{R}^{2}$ becomes 0.735 indicating that the model explains the dependent variable by $73.5 \%$. Furthermore, adding the interaction term to the model containing OCM and supervisory support improved the $\mathrm{R}^{2}$ with a change of 0.011 which is significant at $\mathrm{P}=0.000$. The outcome shows the model explains the changes in the dependent variable by $74.6 \%$. The outcome shows that the moderation role of supervisory support is statistically significant. Additionally, the moderation role of supervisory support is established on the relationship between organizational career management and career satisfaction with $\mathrm{t}=$ 11.523 and significant at 0.000. It also means the relationship between OCM and employee's career satisfaction becomes stronger when supervisors are performing their supporting role as expected of them. The outcome of the moderation role of supervisory support on the said relationship is consistent with the outcome of (Vera et al., 2016). It is believed that career programs put in place by various organizations are not enough to enhance career satisfaction but it also requires the efforts of supervisors to augment the efforts of the organization (Karatepe \& Olugbade, 2017). Supervisors are recognized as one of the main important elements in an organization and are mostly implementers of organizational policies (Goh et al., 2015). Engaging them to contribute to the building of the careers of their subordinates is a step in the right direction (Kang et al., 2015). Based on the outcome of the study, a decision is taken on the proposed hypothesis of the study in table 9.

Table 6 Summary of the hypothesis. 


\begin{tabular}{|l|l|l|}
\hline \multicolumn{2}{|c|}{ Hypothesis } & Result \\
\hline H1 & $\begin{array}{l}\text { There will be a significant and positive impact of OCM on career } \\
\text { satisfaction. }\end{array}$ & Accepted \\
\hline H2 & $\begin{array}{l}\text { There will be a significant and positive impact of supervisory } \\
\text { support on career satisfaction. }\end{array}$ & Accepted \\
\hline H3 & $\begin{array}{l}\text { Supervisory support positively moderates the relationship } \\
\text { between OCM and career satisfaction. }\end{array}$ & Accepted \\
\hline
\end{tabular}

\section{Implications of the study}

Concerning the theoretical contribution contributions of the study, it has been ascertained that employee's career satisfaction is affected by organizational career management but not only does OCM affect career satisfaction it is determined that the inclusion of supervisors to provide supportive actions to the career progression of the employees also leads to career satisfaction. Furthermore, it is established that the introduction of supervisory support strengthens the relationship between organizational career management and career satisfaction. Until now, the study of such moderation role of supervisory support was very rare but has been tested on elements such as OCM and commitment (Kang et al., 2015), OCM, and career adaptability (Guan et al., 2015b; Kang et al., 2015). The outcome of the study also throws wait behind the Job Demand Resource (JD-R) Theory such that organizational career management and supervisory support could be defined as an organizational resource that could be used to promote career satisfaction. This is supported by studies of Cho et al., (2020); Hobfoll et al., (2018); Schaufeli, (2017) which speak to conserving resources in an organizational context and their consequences. The outcome is also consistent with results from Clements \& Kamau, (2018) where motivation and opportunity for career progression were established to be a resource to produce career-related behaviors.

Regarding practical implications, the study has established that OCM can affect the career satisfaction of the employees. OCM measures and practices constantly have been proven by several researchers such as Saleem \& Amin, (2013); Wang \& Wanberg, (2017) to affect the career success and growth of employees which result in satisfaction. OCM activities such as establishing career counseling centers, promotion through the ranks, funded education for employees by the organization, and other career-related programs must be constituted by management by the private insurance companies to ensure career satisfaction. This assertion is supported by (Jackson \& Wilton, 2016; Kang et al., 2015; Rothwell et al., 2015). The benefits produced by OCM are unimaginable and set the platform for achieving career objectives and establishes a long-lasting bond with an organization (Karavardar, 2014; Neary et al., 2015).

Furthermore, enhancing supervisory roles when defining career-related programs should be encouraged. It is believed that the bond between supervisors and their subordinates is mostly deemed stronger (Mineva et al., 2020). Supervisors mostly understand and know the real career needs and the aspect that needs to be developed (Chan, 2017). Therefore, the introduction of supervisors to advance the achievement of the career goals of employees should be duly encouraged. Supervisory support strengthens the relationship between OCM and career satisfaction as it has been established by the study. The management of the private insurance companies must consider improving OCM practices and establish a room for supervisors to contribute their quota to building the careers of the employees. Kang et al., (2015) posit that the management of hotels should be much aware of measures that contribute to the career growth of employees. Fostering appropriate supervisory support would be a source of career satisfaction among employees (Vera et al., 2016). The outcome of the study would help supervisors to appreciate the fact that they should distinguish in their career-related support between levels of organizational career management in managing their subordinates (Poisat et al., 2014; Yang et al., 2018). 


\section{Conclusion}

This research went on the premise of determining the moderating role of supervisory support on the relationship between organizational career management (OCM) and career satisfaction concerning employees of private insurance companies in Ghana. The Cronbach alpha measure was employed to confirm the validity and reliability of the research instrument. Subsequently, the descriptive, correlation multiple regression analysis, and the moderated multiple regression analysis was used to test for the confirmation of the proposed research hypothesis $(\mathrm{H} 1, \mathrm{H} 2 \& \mathrm{H} 3)$ and to determine the relationship between the constructs.

The study established that OCM has a significant and positive impact on the career satisfaction of the study population as shown in table 7 . The study, hence, relays that practices and programs that facilitate career advancement and management should be considered by the private insurance companies as a critical driving force in ensuring their employees are satisfied with their careers. This act may also result in other outcomes such as increased morale, motivation, and long-term commitment.

The study further established that supervisory support has a positive impact on career satisfaction and also affects positively the relationship between OCM and career satisfaction. The researcher hence suggests that the role of supervisors such as the provision of career information, making known available opportunities, implementing career-related programs, giving appropriate feedback among others that affects the career of employees should be well-played and executed by supervisors. Such roles of supervisors speak volumes about their commitment to the career of their subordinates and therefore cannot be undermined. On these bases, the study posits that all proposed hypothesis $(\mathrm{H} 1, \mathrm{H} 2 \& \mathrm{H} 3)$ is all accepted.

\section{Limitations and Recommendations}

This study like any other study has its limitations. Firstly, the study focused on OCM as a single individual construct and did not pay attention to specific OCM programs and practices (e.g., career planning, mentorship, counseling, promotions among others) to determine their specific impact on career satisfaction. Additionally, the sample size for the study which was obtained through a simple random sampling approach is small. An expansion of the sample size may produce contrary results. The nature of the sample size makes it challenging to generalize the outcome of the study.

The study further recommends that future researchers would focus on examining constructs of OCM such as career planning, career opportunities, career development among others because they have been duly recognized to have an important link between career programs and career outcomes (e.g., career mobility, career choices \& career progression). Future researchers could also conduct a study in a different sector or industry other than that of this study using similar constructs.

\section{References}

[1] Arthur, M. B., Khapova, S. N., \& Wilderom, C. P. M. (2005). Career Success in a boundaryless career world. Journal of Organizational Behavior, 26(2), 177-202. https://doi.org/10.1002/job.290

[2] Bakker, A. B., \& Demerouti, E. (2014). Job demands-resources theory. Wellbeing: A Complete Reference Guide: 1-28.

[3] Bakker, A. B., \& Demerouti, E. (2017). Job demands-resources theory: taking stock and looking forward. Journal of Occupational Health Psychology, 22(3), 273.

[4] Carasco-Saul, M., Kim, W., \& Kim, T. (2015). Leadership and employee engagement: Proposing research agendas through a review of the literature. Human Resource Development Review, 14, 3863.

[5] Chan, S. C. (2017). Benevolent leadership perceived supervisory support, and subordinates' performance. Leadership \& Organization Development Journal.

[6] Chiaburu, D. S., Diaz, I., \& De Vos, A. (2013). Employee alienation: Relationships with careerism and career satisfaction. Journal of Managerial Psychology, 18(1), 4-20.

[7] Cho, S., Noh, H., Yang, E., Lee, J., Lee, N., Schaufeli, W. B., \& Lee, S. M. (2020). Examining the job demands-resources model in a sample of Korean correctional officers. Current Psychology, 1-14.

[8] Clements, A. J., \& Kamau, C. (2018). Understanding students' motivation towards proactive career behaviors through goal-setting theory and the job demands-resources model. Studies in Higher Education, 43(12), 2279-2293. 
[9] de Oliveira, L. B., Cavazotte, F., \& Alan Dunzer, R. (2017). The interactive effects of organizational and leadership career management support on job satisfaction and turnover intention. The International Journal of Human Resource Management, 1-21. https://doi.org/10.1080/ 09585192.2017.1298650

[10] De Vos, A., \& Segers, J. (2013). Self-directed career attitude and retirement intentions. Career Development International, 18(2), 155-172.

[11] Fleisher, C., N. Khapova, S., \& G.W. Jansen, P. (2014). Effects of employees' career competencies development on their organizations. Career Development International, 19(6), 700-717. https://doi.org/10.1108/CDI-12-2013-0150

[12] Fukui, S., Wu, W., \& Salyers, M. P. (2019). Impact of supervisory support on turnover intention: The mediating role of burnout and job satisfaction in a longitudinal study. Administration and Policy in Mental Health and Mental Health Services Research, 46(4), 488-497.

[13] Goh, Z., Ilies, R., \& Wilson, K. S. (2015). Supportive supervisors improve employees' daily lives: The role supervisors play in the impact of daily workload on life satisfaction via a work-family conflict. Journal of Vocational Behavior, 89, 65-73.

[14] Guan, Y., Zhou, W., Ye, L., Jiang, P., \& Zhou, Y. (2015a). Perceived organizational career management and career adaptability as predictors of success and turnover intention among Chinese employees. Journal of Vocational Behaviour, 88, 230-237. https://doi.org/https://doi.org/10.1016/j. jvb.2015.04.002

[15] Guan, Y., Zhou, W., Ye, L., Jiang, P., \& Zhou, Y. (2015b). Perceived organizational career management and career adaptability as predictors of success and turnover intention among Chinese employees. Journal of Vocational Behaviour, 88, 230-237. https://doi.org/10.1016/j. jvb.2015.04.002

[16] Hagiwara, Y., Hasegawa, K., Chiba, T., \& Watase, H. (2014). Residency and career satisfaction among Anglo-American model emergency medicine residents in Japan. Acute Medicine \& Surgery, $1,45-53$.

[17] Hair, J. F., Black, W. C., Babin, B. J., \& Anderson, R. E. (2009). Multivariate Data Analysis. (7th Edition). Pearson Education Inc. https://doi.org/http://doi.org/10.1016/j.ijpharm.2011.02.019

[18] Hair, J. F., Black, W. C., Babin, B. J., \& Anderson, R. E. (2010). Multivariate Data Analysis. (7th(ed).). Prentice-Hall.

[19] Hair J, F., Black W, C., Babin, B, J., \& Anderson, R, E. (2010). Multivariate Data Analysis. (7th(ed).). Englewood Cliffs: Prentice-Hall.

[20] Hobfoll, S. E., Halbesleben, J., Neveu, J. P., \& Westman, M. (2018). "Conservation of resources in the organizational context: the reality of resources and their consequences". Annual Review of Organizational Psychology and Organizational Behavior, 5, 103-128.

[21] Ismail, A., Daud, N. G., \& Madrah, H. (2011). Relationship between career program characteristics and job satisfaction in a city-based local authority. Scientific Annals of the "Alexandru Ioan Cuza" University of Iasi, Economic Sciences Section The Romanian Economic Journal, 58, 269-280.

[22] Ismail, A., Nowalid, W. A. W. M., \& Bakar, R. A. (2016). Proactive behavior as a mediator of the relationship between career management and career satisfaction. Jurnal Pengurusan (UKM Journal of Management), 48.

[23] Ismail, A., Nowalid, W. A. W. M., \& Nor, A. M. (2017). Career Administration as a Determinant of Proactive Behavior. Economic Review: Journal of Economics and Business, 15(1), 7-18.

[24] Jackson, D., \& Wilton, N. (2016). Developing career management competencies among undergraduates and the role of work-integrated learning. Teaching in Higher Education, 21(3), 266286.

[25] Jin, M. H., \& McDonald, B. (2017). Understanding employee engagement in the public sector: The role of the immediate supervisor, perceived organizational support, and learning opportunities. The American Review of Public Administration, 47(8), 881-897.

[26] Kalliath, T., Kalliath, P., \& Albrecht, S. L. (2012). The influence of job, team, and organizational level resources on employee well-being, engagement, commitment, and extra-role performance. International Journal of Manpower.

[27] Kang, H. J. (Annette), Gatling, A., \& Kim, J. (Sunny). (2015). The Impact of Supervisory Support on Organizational Commitment, Career Satisfaction, and Turnover Intention for Hospitality Frontline 
Employees. Journal of Human Resources in Hospitality \& Tourism, 14(1), 68-89. https://doi.org/10.1080/15332845.2014.904176

[28] Karatepe, O. M., \& Olugbade, O. A. (2017). The effects of workplace social support and career adaptability on career satisfaction and turnover intentions. Journal of Management \& Organization, 23(3), 337-355.

[29] Karavardar, G. (2014). Organizational career growth and turnover intention: an application in audit firms in Turkey. International Business Research, 7(9), 67.

[30] Kong, H., Cheung, C., \& Song, H. (2012). From hotel career management to employees' career satisfaction: The mediating effect of career competency. International Journal of Hospitality Management, 31, 76-85.

[31] Kong, H., Wang, S., \& Fu, X. (2015). Meeting career expectation: can it enhance job satisfaction of Generation Y?. International Journal of Contemporary Hospitality Management.

[32] Kothari, C. R. (2008). Research Methodology, Methods, and Techniques. (2nd ed.). New Age International (P) Limited.

[33] Kraimer, M. L., Seibert, S. E., Wayne, S. J., Liden, R. C., \& Bravo, J. (2011). Antecedents and outcomes of organizational support for development: The critical role of career opportunities. Journal of Applied Psychology, 96(3), 485.

[34] Lambert, E. G., Minor, K. I., Wells, J. B., \& Hogan, N. L. (2016). Social support's relationship with correctional staff job stress, job involvement, job satisfaction, and organizational commitment. The Social Science Journal, 53(1), 22-32.

[35] Lee, K. J. (2016). Sense of calling and career satisfaction of hotel frontline employees. International Journal of Contemporary Hospitality Management.

[36] Lewis, S., \& Arnold, J. (2012). Organizational career management in the UK retail buying and merchandising community. International Journal of Retail \& Distribution Management, 40(6), 451470.

[37] McGuire, D., Bagher, M., Yap, M., Holmes, M. R., Hannan, C. A., \& Cukier, W. (2010). The relationship between diversity training, organizational commitment, and career satisfaction. Journal of European Industrial Training., https://doi.org/https://doi.org/10.1108/03090591011061202

[38] Mineva, O., Alikaeva, M., \& Minev, V. (2020). TRANSFORMATION OF CAREER MANAGEMENT APPROACHES IN THE DIGITAL SOCIETY. MEST Journal, 8(2), 143-150. https://doi.org/10.12709/mest.08.08.02.16

[39] Neary, S., Dodd, V., \& Hooley, T. (2015). Understanding Career Management Skills: Findings From the First Phase of the CMS Leader Project. University of Derby:

[40] Osibanjo, A. O., Oyewunmi, A. E., \& Ojo, S. I. (2014). Career development as a determinant of organizational growth: Modelling the relationship between these constructs in the Nigerian banking industry. American International Journal of Social Science, 3(7).

[41] Pandey, A., Schulz, E. R., \& Camp, R. R. (2018). The Impact of Supervisory Support for HighPerformance Human Resource Practices on Employee In-Role, Extra-role, and Counterproductive Behaviors 1. Journal of Managerial Issues, 30(1), 97-6.

[42] Paul, C. F. S. N. K., \& Jansen, G. W. (2014). Effects of employees' career competencies development on their organizations: do satisfaction matter?. Career Development International, 19(6), 700-717.

[43] Poisat, P., Mey, M., \& Theron, A. (2014). Supervisory Support Key to Female Career Satisfaction. Mediterranean Journal of Social Sciences. https://doi.org/10.5901/mjss.2014.v5n10p11

[44] Rothwell, W. J., Jackson, R. D., Ressler, C. L., Jones, M. C., \& Brower, M. (2015). Career Planning and Succession Management: Developing Your Organization's Talent-for Today and Tomorrow: Developing Your Organization's Talent-for Today and Tomorrow. ABC-CLIO.

[45] Rucha, B. (2013). Supervisor supportiveness: global perspectives. The Generations of Talent.

[46] Saleem, S., \& Amin, S. (2013). The impact of organizational support for career development and supervisory support on employee performance: An empirical study from Pakistani academic sector. European Journal of Business and Management, 5(5), 194-207.

[47] Schaufeli, W. B. (2017). Applying the job demands-resources model. Organizational Dynamics, 2(46), 120-132. 
[48] Spurk, D., Abele, A. E., \& Volmer, J. (2015). The career satisfaction scale in context: A test for measurement invariance across four occupational groups. Journal of Career Assessment, 23(2), 191209.

[49] Spurk, D., Hirschi, A., \& Dries, N. (2019). Antecedents and outcomes of objective versus subjective career success: Competing perspectives and future directions. Journal of Management, 45(1), 35-69.

[50] Suan, C. L., \& Nasurdin, A. M. (2016). Supervisor support and work engagement of hotel employees in Malaysia. Gender in Management. An International Journal.

[51] Thunnissen, M. (2016). Talent management: For what, how, and how well? An empirical exploration of talent management in practice. Employee Relations, 38(1), 57-72.

[52] van Woerkom, M., Bakker, A. B., \& Nishii, L. H. (2016). Accumulative job demands and support for strength use: Fine-tuning the job demands-resources model using conservation of resources theory. Journal of Applied Psychology, 101(1), 141.

[53] Vera, M., Martínez, I. M., Lorente, L., \& Chambel, M. J. (2016). The Role of Co-worker and Supervisor Support in the Relationship Between Job Autonomy and Work Engagement Among Portuguese Nurses: A Multilevel Study. Social Indicators Research, 126(3), 1143-1156. https://doi.org/10.1007/s11205-015-0931-8

[54] Wang, M., \& Wanberg, C. R. (2017). 100 years of applied psychology research on individual careers: From career management to retirement. Journal of Applied Psychology, 102(3), 546.

[55] Weng, Q., \& McElroy, J. C. (2012). Organizational career growth, affective occupational commitment, and turnover intentions. Journal of Vocational Behavior, 80(2), 256-265.

[56] Wesarat, P., Sharif, M. Y., \& Majid, A. H. A. (2014). A Review of Organizational and Individual Career Management: A Dual Perspective. International Journal of Human Resource Studies, 4(1), 101. https://doi.org/10.5296/ijhrs.v4i1.5331

[57] Wickramasinghe, V. Jayaweera, M. (2010). Impact of career plateau and supervisory support on career satisfaction: A study in offshore outsourced IT firms in Sri Lanka. Career Development International, 15(6), 544-561.

[58] Wickramasinghe, V., \& Jayaweera, M. (2010). Impact of career plateau and supervisory support on career satisfaction: A study in offshore outsourced IT firms in Sri Lanka. Career Development International, 15(6), 544-561.

[59] Yang, F., Liu, J., Huang, X., Qian, J., Wang, T., Wang, Z., \& Yu, H. (2018). How supervisory support for career development relates to subordinate work engagement and career outcomes: The moderating role of task proficiency. Human Resource Management Journal, 28(3), 496-509. https://doi.org/10.1111/1748-8583.12194 